\title{
Towards online repurchase intention: A non-probabilistic approach to unpack its antecedents in Pécs
}

\author{
Frederick Pobee \\ University of Pecs
}

\section{THE AIMS OF THE PAPER}

This research explores the determining factors of online repurchase of online shoppers in Hungary, focusing on Pécs.

\section{METHODOLOGY}

The non-probabilistic sampling technique (convenience sampling) was used to collect cross-sectional data from online shoppers in the city of Pécs. Data was collected from 412 online shoppers. In addition, SmartPLS - Structural equation modeling software was used to investigate the relationships of the hypothesized variables.

\section{MOST IMPORTANT RESULTS}

The research findings suggest that information quality, systems quality, and service quality significantly affect user satisfaction. Consequently, user satisfaction was found to influence consumer repurchase intention significantly.

\section{RECOMMENDATIONS}

The findings present some practical implications for e-vendors and online business web designers. The significant influence of system quality on user satisfaction implies that e-vendors e-commerce web designers should provide quality website features that are reliable, user-friendly, has quick response time, and are available on a 24/7 basis. Also, to ensure user satisfaction and repurchase, e-vendors must give their consumers a satisfying online experience by providing the necessary support in real-time. Disputes from online transactions should be solved as quickly as they arise to the delight of consumers.

Keywords: e-commerce adoption, repurchase, information quality, user satisfaction, systems quality, Hungary

DOI: 10.15170/MM.2021.55.02.05 


\section{INTRODUCTION}

Humans have significantly benefited from the era of globalization in their daily activities. The presence of sophisticated information technology capable of supplementing human needs is one of the conveniences provided. One of the significant developments that have accompanied technological advancement is electronic commerce (e-commerce). According to Qun (2009), E-commerce is the "commercial trade activities carried out by electronic methods, the electronification of traditional trades." In the past few decades, e-commerce has become a buzzword and has gained significant attention in the marketing industry, allowing countries to profit from the perks of online transactions. The exponential increase in internet access has led to an increase in online shoppers over the years. The internet world statistics (2020) reported that e-commerce sales hit $\$ 4.2$ trillion at the end of 2020 , an increase of $16.1 \%$ from the previous year of 2019. Projections show a growth of $18.1 \%$ by the end of 2021, representing an increase in online shopping behavior. Hungary is one of the countries that has witnessed significant strides in the number of online shoppers. A recent study by Nagy (2016) showed an increase in the e-commerce growth rate in Hungary. Nagy (2016) suggested that direct drivers (development level of the Hungarian economy, which reflects in internet and device use) and indirect drivers (monthly salary, household consumption, and inflation) influence e-commerce development in Hungary. Kemeny et al. (2016) measured the quality perception in Hungary's e-commerce and concluded that technology-based components such as system responsiveness and efficiency significantly affect satisfaction and WOM intention.

More so, studies like Pobee and Opoku (2018b), Raza et al. (2019), Schaupp et al. (2010), and Khalilzadeh et al. (2017) have investigated determinants of e-commerce adoption in different contexts. Despite these scholarly contributions, it is essential to state that initial purchase does not guarantee an online repurchase from a consumer perspective. Consumers, repurchase behavior, has become a subject of interest among practitioners (e-vendors) and academics, as recently published studies (Aparico et al. 2021, Mendoza et al. 2021, Lee \& Charles 2021) have investigated some causes of consumer repurchase behavior. However, new questions have emerged concerning online shoppers' repurchase intention after the initial purchase. For example, further questions have been asked about DeLone and Mclean's success model's specific configura- tion in repurchase behavior. Understanding the factors influencing online repurchase intention would give e-vendors a strategic direction to deliver distinctive value to consumers. Pham et al. (2018) called on future research to investigate online repurchase intention. To date, just a few studies, including Szucs et al. (2020) and Kemeny et al. (2016), have explored online repurchase intention in Hungary's context. The literature calls for further research to enhance the understanding of online repurchase intention. To fill this research gap, this study explores the antecedents of online repurchase intention in Pécs, the fifth largest city in Hungary.

The city also serves as the administrative hub of Baranya County. In the past few years, online shopping in Pécs has increased rapidly, causing many brick-and-mortar shops to augment their trade with online stores as well. Typical examples are Tesco online shopping, Spar online, and Ubuy Hungary. Although many people in Pécs still purchase with the traditional brick-and-mortar approach, the technology-savvy residents prefer online shopping these days. Online Shopping in Pécs has advanced beyond readiness. This growth in online purchases has been supported by the introduction of many online shopping applications. Pécs was chosen as the empirical focus for this study because of these distinctive characteristics. This study extends studies like Szucs et al. (2020), Ali et al. (2021), and Salim et al. (2021), who investigated information quality, service quality, and systems quality effects on online purchase by exploring repurchase intention. From the academic perspective, there is a dearth of studies that the DeLone and McLean IS model to investigate online repurchase intention. As a result, this research advances the validation of the model to investigate repurchase intention. Despite DeLone and McLean IS model has been used to study online purchase, further questions have emerged about its specific configuration in repurchase behavior. Addressing this gap matters a lot as it makes a valuable contribution to knowledge.

This research was conducted in Hungary, a transitioned country in central Europe. Hungary has emerged to be one of Europe's fast-growing e-commerce markets (Nagy, 2016). In the recent past, business-to-customer e-commerce has rapidly grown in Hungary's retail sector. In 2019, the online share of Hungary's total retail trade turnover increased by $7.6 \%$, a significant percentage increase from 2017 and 2018 that recorded $6.2 \%$ and $7 \%$, respectively (Statista 2019). It is also reported that $54 \%$ of Hungary's population are online shoppers, and online retail turnover amounted to 781 
billion Hungarian Forints. Hungary was chosen as the empirical focus for this research because of these unique characteristics. The next section of this study presents the theoretical foundation and hypotheses development, followed by the research methodology. After that, the results and analysis, the discussion, and the conclusion.

\section{THEORETICAL FOUNDATION}

DeLone and McLean success model was created by DeLone and McLean (2003) to understand the determinants of information systems (IS) use and satisfaction. The first model, which DeLone and McLean (1992) proposed, introduced a comprehensive taxonomy comprised of six IS success measurements: systems quality, information quality, use, user satisfaction, individual impact, and organizational impact. DeLone and McLean (1992) taxonomy drew inspiration from Mason (1978) that adapted a mathematical theory of communication proposed by Shannon and Weaver (1949). Shannon and Weaver's (1949) theory suggested three categories of information; technical level (efficiency and accuracy of the system that produced it), semantic level (ability to transfer the intended message), and effectiveness level (impact on the receiver). Eventually, Mason (1978) adapted and applied this theory in information systems. Mason (1978) suggested that his adapted theory of information systems shows that merging information systems and systems quality would have a more meaningful impact on user satisfaction. Based on this recommendation, DeLone and McLean (1992) developed their original DeLone and McLean IS success model. After a decade, DeLone and McLean (2003) updated the original model to include an original variable, "service quality." This update followed after many researchers argued and criticized the original model (Li 1997, Pitt et al. 1995, Kettinger \& Lee 1994) for not including service quality, an essential determining factor of information system success.

The updated DeLone and McLean IS success model posits that information quality, system quality, and service quality influence users' information system use and satisfaction. After its development, the model has been applied and empirically tested in many research fields, including e-learning (Aldholay et al. 2018, Kurt 2019), e-banking (Rahi \& Ghani 2018, Jaafreh 2017, Tam \& Oliveira 2016), e-governance (Veeramootoo et al. 2018, Stefanovic et al. 2016), cloud computing (Al-Shargabi \& Sabri 2016, Cheng 2018), e-commerce (Angelina et al.
2019, Cui et al. 2019, Ali et al. 2017). Evidence shows that the DeLone and McLean information systems success model is a theoretically and practically grounded theory for investigating social phenomena. For this reason, the author adopted the model's variables to unpack the antecedents of online repurchase intention. The importance of this study is two-fold;

1. The model provides a theoretical lens to explore antecedents of online shoppers repurchase intention, and

2. This study empirically tests and provides Hungarian perspectives on the variables of the model.

\section{HYPOTHESES DEVELOPMENT}

\section{Information quality (IQ)}

Information quality (IQ) refers to the degree of excellence of the content presented in an information system (DeLone \& McLean 2003). In the context of e-commerce, IQ may measure the extent of the excellence of e-commerce content presented on the e-commerce website. Generally, people are inclined towards e-commerce websites that provide relevant, complete, and easy-to-understand content. On the contrary, when e-commerce websites do not provide relevant content, they may not satisfy users' desires. Extant studies have reported the relationship between IQ and user satisfaction. Ali et al. (2021) suggested that the quality of information influence consumers' engagement with travel apps. Similarly, Shim and Jo (2020) found that users' satisfaction and intention to reuse online health information sites are significantly predicted by information quality. Jaafreh (2017) suggested a significant relationship between IQ and users' satisfaction towards e-banking platforms. Likewise, Rahi and Ghani (2018) revealed a significant effect between IQ and users' satisfaction and continuance intention to use e-banking services. Similarly, Tam and Oliveira (2016) found a significant impact of IQ on the satisfaction of m-banking users. Following this basis, the author considers the IQ of e-commerce websites to influence user satisfaction significantly. As a result, the study hypothesized;

H1. Information quality significantly influences user's satisfaction with online shopping. 


\section{System quality (SQ)}

Service quality (SQ) refers to the desired information system features (DeLone \& McLean 2003). In e-commerce, quality e-commerce online features such as website reliability, response time, userfriendly interface, and website availability may increase users' propensity to use and shop on the website. Prior studies have reported the relationship between SQ and user satisfaction. Ebrahim et al. (2021) suggested a significant association between system quality and the use of e-learning platforms. This finding is consistent with Jin and Xu (2020), who found a significant association between system quality and user satisfaction. A study by Angelina et al. (2019) concluded a significant relationship between SQ and users' satisfaction with e-commerce. Equally, Ali et al. (2017) suggested a significant effect of SQ on user satisfaction of e-commerce platforms. Cui et al. (2019) suggested a significant impact of SQ on user satisfaction of cross-border e-commerce. Following this basis, the author considers SQ of e-commerce websites as a significant factor that influences users' satisfaction; hence hypothesized;

$\mathrm{H} 2$. System quality significantly influences users' satisfaction with online shopping.

\section{Service quality (SerQ)}

According to DeLone and McLean (2003), service quality (SerQ) measures the degree of organizational and technical support the developer of an information system provides his consumers. SerQ is an essential variable in an e-commerce context because when users do not get the necessary technical support, they become disgruntled, and e-vendors lose sales. According to Salim et al. (2021), service quality significantly influences user satisfaction.
Yakubu and Dasuki (2018) suggested a significant influence of service quality on user satisfaction with e-learning systems. This finding aligns with Wang and Liao (2008), who suggested a significant association of service quality with user satisfaction of e-government systems. In the same line, Tsao et al. (2016) suggested a significant influence of service quality on consumer/seller relationship user satisfaction. For this research, SerQ is conceptualized as the extent that consumers perceive technical and organizational support from the websites of e-vendors.

H3. Service quality significantly influences users' satisfaction with online shopping.

\section{User satisfaction (US.)}

Prior studies have reported the influence of online users' satisfaction on their repurchase intention (Nguyen et al. 2021, Cha \& Lee 2021, Jain et al. 2021, DeLone \& McLean 2003, Rahi \& Ghani 2018, Cui et al. 2019, Nugroho et al. 2019, Cheng 2018). Cha and Lee (2021) found user satisfaction as a significant predictor of repurchase intention. Rahi and Ghani (2018) revealed a significant influence of user satisfaction on internet banking's continuous use. Likewise, Cheng 2018) showed a significant association between user satisfaction and the continuous intention to use cloud ERP. The findings of Nugroho et al. (2019) suggested a significant relationship between user satisfaction and the continuous intention to use e-learning software. This study makes a case from the findings above that satisfied online shoppers in Hungary will like to repurchase online; hence, hypothesized;

H4. User satisfaction significantly influences users' repurchase intention.

The research model is presented in Figure 1.

Figure 1. The research Model

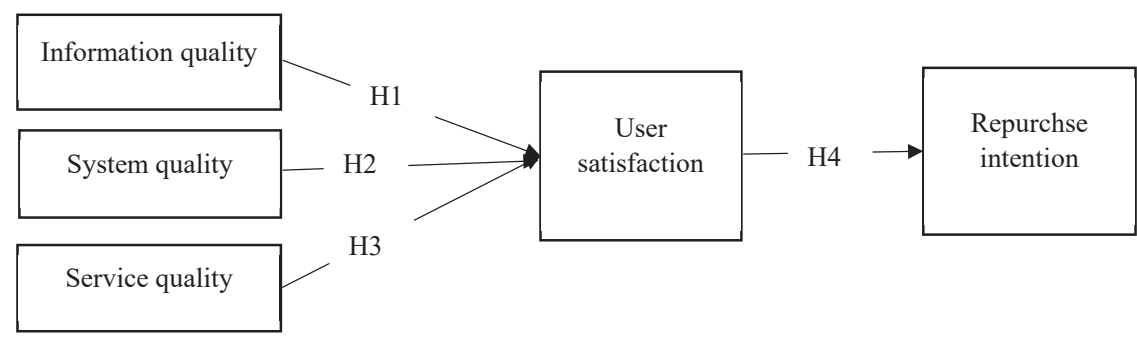

Source: Adapted from DeLone and McLean (2003) 


\section{RESEARCH METHODOLOGY}

\section{Participants and survey instrument}

A non-probabilistic technique to data collection (convenience data sampling technique) was employed to collect data. Data was collected through an online survey containing eighteen (18) items from Hungarian online shoppers in the city of Pécs from January 5, 2021, to March 9, 2021. The survey questionnaire was in two sections. With the assistance of two Hungarian colleagues, the measurement items were translated to Hungarian. To guarantee the validity of the translation, a two-stage process was followed. First, the English items were translated to Hungarian, and after that, the Hungarian items were translated to English to see if items in both languages resonate. Respondents' demographic information such as age, gender, educational status, products purchased, and years of experience with online shopping were gathered in the first section. The second section was on the items related to the hypothesized variables on the factors that may influence user satisfaction and repurchase intention. It was necessary to conduct a pilot survey to ensure that the items reflect the study's objectives. As a result, the questionnaire was pilot-tested with ten respondents, and their responses showed that the questionnaire items could provide valuable data to test the suggested hypothesis.

To estimate the sample size, Hair et al. (2011) rule on sample estimation was used. The rule suggests that an empirical study's sample size should be ten times the largest number of the hypothesized path in a research model. The highest number of the hypothesized path in this research is five. So, going by the ten times rule, a sample size of 40 (4 x 10) is considered sufficient. However, there was the need to adequately sample respondents to represent the population to achieve better generalization. Consequently, the online questionnaire was distributed to 487 people. From this number, 412 responses were fully completed and were deemed suitable for analysis.

The survey items were measured on a five-point Likert scale ranging from 1 "strongly disagree" to 5 "strongly agree." In order to measure the variables adopted in this study, the measurement items were adopted from Wang (2008). Information quality was measure with four items; system quality was measured with four items; service quality was measured with four items; user satisfaction was measured with three items, and repurchase intention was measured with three items. The e-shops that the questions of the questionnaire referred to are online shops that the respondent frequently visits. Frequently visited e-shop was chosen because e-shoppers are assumed to be familiar with the e-commerce websites they usually visit. With this familiarity, consumers may provide critical information on their repurchase intention. Respondents of the survey are Hungarian citizens with experience with online shopping. The data was analyzed using SmartPLS-Structural equation modeling software. 
Table 1. Questionnaire items

\begin{tabular}{|c|c|c|c|}
\hline Variable & Code & Item text & Source \\
\hline \multirow[t]{4}{*}{ Information quality (IQ.) } & IQ1 & $\begin{array}{l}\text { I get the precise information I need on e-com- } \\
\text { merce websites. }\end{array}$ & Wang (2008) \\
\hline & IQ2 & $\begin{array}{l}\text { The e-commerce websites I use meets my infor- } \\
\text { mation needs. }\end{array}$ & \\
\hline & IQ3 & $\begin{array}{l}\text { The information I see on the e-commerce sites } \\
\text { is reliable. }\end{array}$ & \\
\hline & IQ4 & $\begin{array}{l}\text { The e-commerce website provides me with new } \\
\text { information. }\end{array}$ & \\
\hline \multirow[t]{4}{*}{ System quality (SQ.) } & SQ1 & The e-commerce website is user-friendly to me. & \\
\hline & SQ2 & The e-commerce website is simple to use for me & \\
\hline & SQ3 & $\begin{array}{l}\text { The E-commerce system offers me appropriate } \\
\text { functionality. }\end{array}$ & \\
\hline & SQ4 & $\begin{array}{l}\text { I find the e-commerce system to be well struc- } \\
\text { tured }\end{array}$ & \\
\hline \multirow[t]{4}{*}{ Service quality (SerQ) } & SerQ1 & $\begin{array}{l}\text { The customer support for the e-commerce sys- } \\
\text { tem can assist me. }\end{array}$ & \\
\hline & SerQ2 & $\begin{array}{l}\text { The e-commerce website provides me with per- } \\
\text { sonalized services. }\end{array}$ & \\
\hline & SerQ3 & $\begin{array}{l}\text { The e-commerce system service understands } \\
\text { my specific needs. }\end{array}$ & \\
\hline & SerQ4 & $\begin{array}{l}\text { When I have a complaint, the customer support } \\
\text { of the e-commerce website shows genuine inte- } \\
\text { rest in resolving it. }\end{array}$ & \\
\hline \multirow[t]{3}{*}{ User satisfaction (US.) } & US1 & I am satisfied with e-commerce systems & \\
\hline & US2 & I am delighted with the e-commerce website & \\
\hline & US3 & $\begin{array}{l}\text { The e-commerce system has met my expecta- } \\
\text { tion }\end{array}$ & \\
\hline \multirow[t]{3}{*}{ Repurchase intention (RI.) } & RI1 & $\begin{array}{l}\text { I expect to repurchase, assuming I have access } \\
\text { to the e-commerce system. }\end{array}$ & \\
\hline & $\mathrm{RI} 2$ & $\begin{array}{l}\text { In the future, I would repurchase using an } \\
\text { e-commerce website }\end{array}$ & \\
\hline & $\mathrm{RI} 3$ & $\begin{array}{l}\text { I will frequently use the e-commerce system for } \\
\text { repurchase in the future }\end{array}$ & \\
\hline
\end{tabular}

Source: own construction 


\section{RESULTS AND ANALYSIS}

\section{Demographic profile of respondents}

The respondents' demographics (Table 2) indicate that 214 respondents were males and 198 were females. These numbers indicate that male and female respondents are $52 \%$ and $48 \%$, respectively. Regarding the respondents' ages, $26 \%$ ranged from $18-24,32 \%$ ranged from $25-30,31 \%$ ranged from $31-40$, and $11 \%$ ranged from $41-50$. These percentages represent absolute numbers of 107, 132, 128, and 45, respectively. Regarding educational back- ground, 227 respondents have attained bachelors, 177 have attained masters, and 8 have a doctorate. Of products purchased online, 199 respondents bought books, 202 bought clothes, 54 bought computer accessories, and 37 bought home appliances, representing $29 \%, 49 \%, 13 \%$, and $9 \%$, respectively of total respondents. These results show that books are the most purchased product. More so, the respondents with less than five years of online shopping experience are 177, and those with more than five years are 235 , representing $43 \%$ and $57 \%$ of respondents, respectively.

Table 2. Demographic profile of respondents

\begin{tabular}{|c|c|c|}
\hline Variable & Frequency $(n=412)$ & Percentage (\%) \\
\hline \multicolumn{3}{|l|}{ Gender } \\
\hline Male & 214 & 52 \\
\hline Female & 198 & 48 \\
\hline \multicolumn{3}{|l|}{ Age } \\
\hline $18-24$ & 107 & 26 \\
\hline $25-30$ & 132 & 32 \\
\hline $31-40$ & 128 & 31 \\
\hline $41-50$ & 45 & 11 \\
\hline \multicolumn{3}{|l|}{ Educational level } \\
\hline Bachelors & 227 & 55 \\
\hline Masters & 177 & 43 \\
\hline Doctorate & 8 & 2 \\
\hline \multicolumn{3}{|l|}{ Product purchased } \\
\hline Books & 119 & 29 \\
\hline Clothes & 202 & 49 \\
\hline Computer accessories & 54 & 13 \\
\hline Home appliances & 37 & 9 \\
\hline \multicolumn{3}{|c|}{ Years of experience with e-commerce } \\
\hline $1-5$ & 177 & 43 \\
\hline More than 5 years & 235 & 57 \\
\hline
\end{tabular}

Source: Survey data 


\section{Measurement model estimation}

The questionnaire items' validity and reliability were tested using CFA (maximum likelihood estimation method). All factor loadings emerged adequately high and acceptable. In addition, loadings exceeded Hair et al. (2010) threshold of 0.70 . Each construct showed an acceptable internal consistency with Cronbach's alpha estimates ranging from 0.796 to 0.878 (Hair et al. 2010).
The composite reliabilities revealed an adequate internal consistency of multiple items for each construct with composite reliability values above 0.70 (Hair et al. 2010). According to Bagozzi \& Yi (2012) and Hair et al. (2010), the average variance extracted (AVE) of all constructs must be greater than or equal to 0.50 . Table 3 shows that the average variance extracted of all the constructs is above 0.50 , explaining a large portion of the variance.

Table 3. Factor loadings and reliability analysis

\begin{tabular}{|c|c|c|c|c|c|}
\hline Constructs & Codes & Loadings & Cronbach's alpha & CR & AVE \\
\hline \multirow[t]{4}{*}{ Information quality } & IQ1 & 0.868 & 0.825 & 0.852 & 0.621 \\
\hline & IQ2 & 0.899 & & & \\
\hline & IQ3 & 0.828 & & & \\
\hline & IQ4 & 0.819 & & & \\
\hline \multirow[t]{4}{*}{ Systems qulity } & SQ1 & 0.843 & 0.878 & 0.858 & 0.660 \\
\hline & SQ2 & 0.851 & & & \\
\hline & SQ3 & 0.846 & & & \\
\hline & SQ4 & 0.809 & & & \\
\hline \multirow[t]{4}{*}{ Service quality } & SERQ1 & 0.747 & 0.796 & 0.772 & 0.561 \\
\hline & SERQ2 & 0.718 & & & \\
\hline & SERQ3 & 0.801 & & & \\
\hline & SERQ4 & 0.818 & & & \\
\hline \multirow[t]{3}{*}{ User satisfaction } & US1 & 0.866 & 0.856 & 0.832 & 0.712 \\
\hline & US2 & 0.878 & & & \\
\hline & US3 & 0.895 & & & \\
\hline \multirow[t]{3}{*}{ Repurchase intention } & RI1 & 0.815 & 0.873 & 0.851 & 0.799 \\
\hline & RI2 & 0.879 & & & \\
\hline & RI3 & 0.802 & & & \\
\hline
\end{tabular}

Source: Survey data 
Table 4 provides the values of the heterotrait-monotrait ratio (HTMT) of correlations. The maximum value is 0.738 , which is nicely below
0.90, the most conservative critical HTMT value. (Henseler et al. 2015). Therefore we conclude that discriminant validity has been established.

Table 4. Heterotrait-Monotrait ratio (HTMT)

\begin{tabular}{llllll}
\hline & IQ & SQ & SERVQ & US & RI \\
\hline IQ & & & & \\
SQ & 0.455 & & & \\
SERVQ & 0.286 & 0.718 & & \\
US & 0.395 & 0.545 & 0.738 & & \\
RI & 0.690 & 0.347 & 0.426 & 0.396 & \\
\hline
\end{tabular}

Source: Survey data

\section{Model Goodness of fit}

Several model fit indices such as root mean squared error of approximation (RMSEA), comparative fit index (CFI), chi-square/degree of freedom (CMIN/ $\mathrm{DF}$ ), and goodness of fit (GFI) were assessed to evaluate the model fit as presented in Table 5. As a result, the overall model fit conditions are met.

Table 5. The model of fit

\begin{tabular}{llll}
\hline Goodness of fit & $\begin{array}{l}\text { Recommended threshold } \\
\text { (Hoyle and Panter, 1995) }\end{array}$ & SEM value & Remark \\
\hline $\begin{array}{l}\text { Comparative fit index (CFI) } \\
\text { Root mean squared error of approximation } \\
\text { (RMSEA) }\end{array}$ & $\geq .90$ & 0.907 & Good fit \\
Normed fit index (NFI) & $\geq .90$ & 0.037 & Good fit \\
Goodness of fit (GFI) & $\geq .90$ & 0.933 & Good fit \\
Chi-square/degree of freedom (CMIN/DF) & $\leq 3.0$ & 0.939 & Good fit \\
\hline
\end{tabular}

Source: Survey data

\section{Structural model estimation}

The results of the structural equation modeling indicate that information quality is significantly associated with user satisfaction $(\beta=0.447, \mathrm{p}<0.05)$; thus, H1 was supported. The SEM results showed a significant effect of system quality on user satisfaction $(\beta=0.651, \mathrm{p}<0.01)$; thus, H2 was supported.
Similarly, the results confirmed a significant effect of service quality on user satisfaction $(\beta=0.357, \mathrm{p}$ $<0.05)$; thus, H3 was supported. Finally, user satisfaction significantly influences repurchase intention $(\beta=0.511, \mathrm{p}<0.01)$; thus, H4 was supported. Figure 2 shows the model estimation. 
Figure 2. Research model estimation

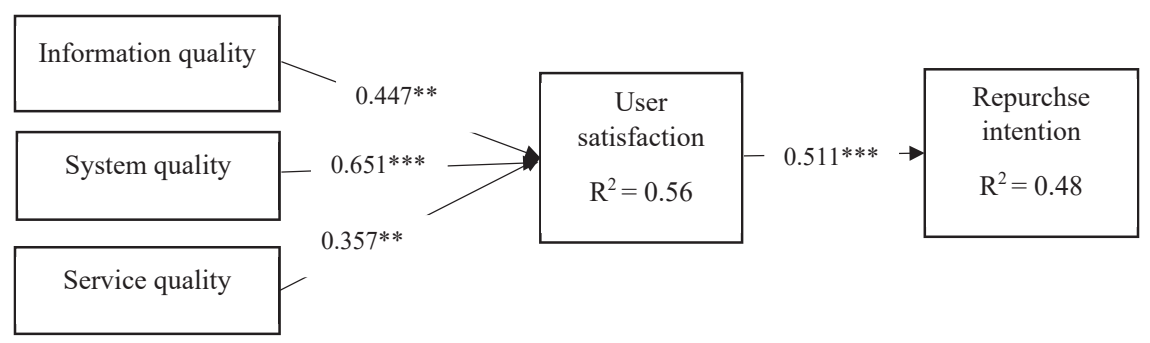

Sig. ${ }^{\mathrm{p}}<0.10 ; * * \mathrm{p}<0.05 ; * * * \mathrm{p}<0.01$

Source: Survey data

\section{DISCUSSION}

The findings of this research indicate that information quality significantly influences user satisfaction of e-commerce. This finding implies that precise information on e-commerce websites, the reliability of the information provided, and the newness of the information affect users' satisfaction. This finding aligns with Ali et al. (2021), Shim \& Jo (2020), Rahi \& Ghani (2018), Jaafreh (2017), and Tam \& Oliveira (2016).

The findings also showed that system quality has a significant influence on user satisfaction. This finding implies that the features of an e-commerce system, such as the user-friendliness of the website interface, availability, reliability, and response time of the e-commerce website, significantly influence the satisfaction of Hungarian online shoppers. This finding is in line with prior research such as Ebrahim et al. (2021), Jin \& Xu (2020), Tsao et al. (2016), Hsu \& Chen (2007), and Angelina et al.
(2019). It is essential to state that the SEM results indicate that systems quality is the strongest predictor of user satisfaction.

More so, the findings revealed a significant relationship between service quality and user satisfaction. This finding implies that the support, being it technical or organizational, that Hungarian online shoppers get from e-vendors and e-commerce website designers significantly influence their satisfaction. This finding corroborates Salim et al. (2021), Yakubu \& Dasuki (2018), and Tsao et al. (2016). Finally, the findings suggested a significant influence of user satisfaction on repurchase intention. When consumers are delighted with products provided via e-vendors websites, it translates into a repurchase intention. Cha \& Lee (2021), Nguyen et al. (2021), Rahi \& Ghani (2018), Cheng (2018), and Nugroho et al. (2019) have reported similar findings. A summary of the results is presented in Table 7 .

Table 7. Summary of results

\begin{tabular}{lccc}
\hline Hypothesis & Beta estimate & p-value & Supported? \\
\hline $\mathrm{IQ} \longrightarrow$ US & 0.447 & $\mathrm{p}>0.05$ & Yes \\
$\mathrm{SQ} \longrightarrow$ US & 0.651 & $\mathrm{p}<0.01$ & Yes \\
$\mathrm{SerQ} \longrightarrow$ US & 0.357 & $\mathrm{p}<0.05$ & Yes \\
$\mathrm{US} \longrightarrow$ RI & 0.511 & $\mathrm{p}<0.01$ & Yes \\
\hline
\end{tabular}

Source: Survey data 


\section{THEORETICAL CONTRIBUTION}

The dearth of research on online shoppers' repurchase intention, particularly in Hungary, has created a research gap in the literature that needs scholarly attention. This study applied the DeLone and McLean IS success model to investigate Hungarians' online shopping repurchase intention as a theoretical contribution. More substantial theoretical claims cannot be made regarding the influencing factors of repurchase behavior with the diminutive research on online repurchase intention within the Hungarian context. Thus, this research augments the existing literature and advances it by investigating beyond initial purchase intention to explore repurchase intention.

\section{PRACTICAL IMPLICATION}

The findings present some practical implications for e-vendors and online business web designers. The significant influence of system quality on user satisfaction implies that e-vendors e-commerce web designers should provide quality website features that are reliable, user-friendly, has quick response time, and are available on a 24/7 basis. Also, to ensure user satisfaction and repurchase, e-vendors must give their consumers a satisfying online experience by providing the necessary support in real-time. Furthermore, disputes from online transactions should be solved as quickly as they arise to the delight of consumers. Finally, e-vendors must know and define who their customers are and provide information that fits their purpose. The information must be unique, timely, valid, consistent, accurate, and complete.

\section{LIMITATIONS AND FUTURE RESEARCH LINES}

The research sampled online shoppers from one out of the many cities in Hungary. This may distort the generalization of the findings to the country's population. Future research should investigate the other cities to provide a clearer and better understanding of online consumers' repurchase behavior. Second, this research employed a non-probabilistic sampling technique (convenience sampling) to sample respondents. This method may not necessarily capture the populations' view; future studies may adopt a probabilistic sample technique that reduces sampling bias and increases the reliability of research findings. Third, research findings best describe well-educated, frequent e-shoppers because of the bias in sample distribution. It is unknown if the findings directly apply to the less educated and infrequent or irregular e-shoppers. Future research can examine the online repurchase intention in this category of online shoppers. These results can be used as a basis for comparative studies. 


\section{REFERENCES}

Aldholay, A., Osama, I., Abdullah, Z., Alrajawy, I. and Nusari, M. (2018), "The Role of Compatibility as a Moderating Variable in the Information System Success Model: The Context of Online Learning Usage," International Journal of Management and Human Science, 2 1, 9-15.

Ali, A., Rasool, G. and Pathania, A. (2017), "Antecedents for success of e-commerce platforms: an investigative approach," Int. J. Information Technology and Management, 16 4, 376-390.

Ali, F., Terrah, A., Wu, C., Ali, L. and Wu, H. (2021), "Antecedents and consequences of user engagement in smartphone travel apps," Journal of Hospitality and Tourism Technology. https://doi. org/10.1108/JHTT-09-2020-0221.

Al-Shargabi, B. and Sabri, O. (2016), "A study of Adopting Cloud Computing from Enterprise Perspective using DeLone and Mclean IS Success Model," International Journal of Computer Science and Information Security, 14, 32-38.

Angelina, R., Hermawan, A. and Suroso, A. (2019), "Analyzing E-Commerce Success using DeLone and McLean Model," Journal of Information Systems Engineering and Business Intelligence, $52,156-162$.

Aparico, M., Costa, C. and Moises, R. (2021), "Gamification and reputation: key determinants of e-commerce usage and repurchase intention," Heliyon, 7. https://doi.org/10.1016/j.heliyon.2021.e06383.

Bagozzi, R. P. \& Yi., Y. (2012), Specification, evaluation, and interpretation of structural equation models. Journal of the Academy of Marketing Science, 40 1, 8-34.

Cha, S. and Lee, S. (2021), "The Effects of User Experience Factors on Satisfaction and Repurchase Intention at Online Food Market," Journal of Industrial \& Business, 12 4, 7-13.

Cheng, Y. (2018), "A hybrid model for exploring the antecedents of cloud ERP continuance: Roles of quality determinants and task-technology fit," International Journal of Web Information Systems, 15 2, 215-235.

Cui, Y., Mou, J., Cohen, J. and Liu, Y. (2019), "Understanding information system success model and valence framework in sellers' acceptance of cross-border e-commerce: a sequential multi-method approach," Electronic Commerce Research, 19, 885-914.

DeLone, W. and McLean, E. (1992), "Information systems success: the quest for the dependent variable," Information Systems Research, 3 1, 60-95.

DeLone, W. and McLean, E. (2003), "The DeLone and McLean model of information systems success: A ten-year update," Journal of Management Information Systems, 19 4, 9-30.
Ebrahim, R. S., Afify, W. and Abdelkareem, R. S. (2021), "Integrating student engagement with the DeLone \& McLean model to assess the effectiveness of Online Learning System during COVID19 pandemic," Scientific Journal for Financial and Commercial Studies and Researches, 21 , 384- 424.

Hair, J. F., Black, W. C., Babin, B. J. \& Anderson, R. E. (2010), Multivariate Date Analysis. (7thed.), Singapore: Pearson Education Ltd.

Henseler, J., Ringle, C. M. and Sarstedt, M. (2015), "A new criterion for assessing discriminant validity in variance-based structural equation modeling," Journal of the Academy of Marketing Science, 43, 115-135.

Internet world statistics (2020), "E-commerce share of total global retail sales from 2015 to 2023 ". https://www.statista.com/statistics/534123/ecommerce-share-of-retail-sales-worldwide/

Jaafreh, A. (2017)," Evaluation Information System Success: Applied DeLone and McLean Information System Success Model in Context Banking System in KSA," International Review of Management and Business Research, 62, 829-845.

Jain, N., Gajjar, H. and Shah, B. (2021), "Electronic logistics service quality and repurchase intention in e-tailing: Catalytic role of shopping satisfaction, payment options, gender and returning experience," Journal of Retailing and Consumer Service, 59. https://doi.org/10.1016/j.jretconser.2020.102360

Jin, X. and Xu. F. (2020), "Examining the factors influencing user satisfaction and loyalty on paid knowledge platforms," Journal of Information Management. DOI 10.1108/AJIM-07-20200228 .

Kemeny, I., Simon, J., Nagy, A. and Szucs, K. (2016), "Measuring quality perception in electronic commerce: A possible segmentation in the Hungarian market," Industrial Management \&Data Systems, 116 9, 1946-1966.

Kettinger, W.J. and Lee, C.C. (1994), "Perceived service quality and user satisfaction with the information services function," Decision Sciences, 25 5/6, 737-766.

Khalilzadeh, J., Ozturk, A. and Bilgihan, A. (2017), "Security-related factors in extended UTAUT model for NFC based mobile payment in the restaurant industry," Computers in Human Behaviour, 70, 460-474.

Kurt, O. (2019), "Examining an e-learning system through the lens of the information systems success model: Empirical evidence from Italy," Education and Information Technologies, 24, 1173-1184.

Lee, L. and Charles, V. (2021), "The impact of consumers' perceptions regarding the ethics of online retailers and promotional strategy on 
their repurchase intention," International Journal of Information Management, 57. https://doi. org/10.1016/j.ijinfomgt.2020.102264.

Li, EY (1997), "Perceived importance of information system success factors: a meta-analysis of group differences," Information and Management, 32 $1,15-28$

Mason, R.O. (1978), "Measuring information output: a communication systems approach," Information and Management, 1 4, 219-234.

Mendoza, E. (2021), "A Study of Online Customers Repurchase Intention Using the 4Rs of Marketing Framework," International Review of Management and Marketing, 11 2, 1-10.

Nagy, S. (2016), "E-commerce in Hungary: A market Analysis," Club of Economics in Miskolc, 12 2, 25-32.

Nguyen, L., Nguyen, T. and Tan, T. (2021), “An Empirical Study of Customers' Satisfaction and Repurchase Intention on Online Shopping in Vietnam," Journal of Asian Finance, Economics and Business, 8 1, 971-983.

Nugroho, M., Setyorini, D. and Novitasari, B. (2019), "The Role of Satisfaction on Perceived Value and E-Learning Usage Continuity Relationship," Procedia Computer Science, 161, 82-89.

Pham, Q., Tran, X., Misra, S., Maskeliunas, R. and Damasevicius, R. (2018), "Relationship between Convenience, Perceived Value, and Repurchase Intention in Online Shopping in Vietnam," Sustainability, 10 2, 156-169.

Pitt, L.F., Watson, R.T. and Kavan, C.B. (1995), "Service quality: a measure of information systems effectiveness," MIS Quarterly, 19 2, 173 187.

Pobee, F. and Opoku, D. (2018b), "The Moderating Effects of Gender on E-Commerce Systems Adoption Factors," International Journal of Strategic Decision Sciences, 9 4, 86-104.

Qun, Z. (2009), “Introduction to e-commerce”. New York, NY: Springer.

Rahi, S. and Ghani, M. (2018), "Integration of DeLone and McLean and self-determination theory in internet banking continuance intention context. International Journal of Accounting \& Information Management, 27 3, 512-528.

Raza, S., Shah, N. and Ali, M. (2019), "Acceptance of mobile banking in Islamic banks: Evidence from modified UTAUT model," Journal of Islamic Marketing, 10 1, 357-376

Salim, M., Alfansi, L., Anggarawati, S. Saputra, F. and Afandy, C. (2021), "The role of perceived usefulness in moderating the relationship between the DeLone and McLean model on user satisfaction. Uncertainty Supply Chain Management, 9. doi: 10.5267/j.uscm.2021.4.002.

Schaupp, L. C., Carter, L. and McBride, M. (2010), "E-file adoption: a study of US taxpayers' inten- tions," Computers in Human Behavior, 26 4, 636-644.

Shannon, C. and Weaver, W. (1949), "The Mathematics Theory of Communication." Univ. IL Press, Urbana.

Shim, M. and Jo, H. (2020), "What quality factors matter in enhancing the perceived benefits of online health information sites? Application of the updated DeLone and McLean Information Systems Success Model. Journal of Medical Informatics," 137, https://doi.org/10.1016/j. ijmedinf.2020.104093.

Statista (2019), "Value of online retail trade turnover in Hungary from 2005 to 2019," https://www.statista.com/statistics/668710/eretail-revenue-hungary/

Stefanovic, D., Marjanovic, U., Delic, M., Culibrk, D. and Lalic, B. (2016), "Assessing the success of e-government systems: An employee perspective," Information \& Management, 53, 717-726.

Szucs, K., Nagy, A., Kemény, I. and Simon, J. (2020), Relationshipbetween customer satisfaction and the recommendation and repurchase intention inonline shopping environment. Proceedings of the European Marketing Academy, 49th, (64118)

Tam, C. and Oliveira, T. (2016), Understanding the impact of $\mathrm{m}$-banking on individual performance: DeLone \& McLean and TTF perspective," Computers in Human Behavior, 61, 233-244.

Tsao, W., Hsieh, M. and Lin, T. (2016), "Intensifying online loyalty! The power of website quality and the perceived value of consumer/seller relationship," Industrial Management \& Data Systems, $1169,1987-2010$.

Veeramootoo, N., Nunkoo, R. and Dwivedi, Y. (2018), "What determines success of an e-government service? Validation of an integrative model of e-filing continuance usage," Government Information Quarterly, 35, 161-174.

Wang, Y. and Liao, Y. (2008), “Assessing eGovernment systems success: A validation of the DeLone and McLean model of information systems success," Government Information Quarterly, 25, 717-733.

Yakubu, M. and Dasuki, S. (2018), "Assessing eLearning systems success in Nigeria: an application of the DeLone and McLean Information Systems Success Model," Journal of Information Technology Education Research, 17, 183-203.

Frederick Pobee, PhD Student pobee.fred@gmail.com

University of Pecs Faculty of Business and Economics 